Wahana Akademika

Volume 5 Nomor 2, Oktober 2018

\title{
PENGARUH KEPEMIMPINAN KEPALA SEKOLAH, KOMPETENSI PEDAGOGIK DAN KOMPETENSI PROFESIONAL GURU TERHADAP KINERJA GURU SMK BISNIS MANAJEMEN DI KABUPATEN KLATEN
}

\author{
Ita Nurmalasari, \\ itanurmalasari75@gmail.com
}

\begin{abstract}
Abstrak
Penelitian ini bertujuan untuk mengetahui: (1) Pengaruh kompetensi profesional terhadap kinerja guru akuntansi SMK bisnis manajemen di Kabupaten Klaten, dan (2) Pengaruh kepemimpinan kepala sekolah, kompetensi pedagogik dan kompetensi profesional guru secara bersama-sama terhadap kinerja guru akuntansi SMK bisnis manajemen di Kabupaten Klaten. Penelitian ini merupakan jenis penelitian ex-post facto dengan pendekatan kuantitatif. Populasi dalam penelitian ini yaitu seluruh guru akuntansi SMK bisnis manajemen di Kabupaten Klaten sejumlah 73 guru dari 15 sekolah. Instrumen pengumpulan data yang digunakan yaitu kuesioner. Teknik analisis data menggunakan teknik analisis data deskriptif dan analisis regresi ganda. Hasil penelitian ini yaitu sebagai berikut. (1) Tidak ada pengaruh kompetensi profesional terhadap kinerja guru akunansi SMK bisnis manajemen di Kabupaten $(\beta=0,643$, sig = 0,522). (2) Ada pengaruh kepemimpinan kepala sekolah, kompetensi pedagogik, dan kompetensi profesional guru secara bersama-sama terhadap kinerja guru SMK bisnis manajemen di Kabupaten Klaten $(F=33,584$, sig = 0,000).
\end{abstract}

Kata Kunci: Kinerja Guru, SMK

\begin{abstract}
This study aims at knowing: (1) The influence of proffesional competence on accounting teacher's performance at vocation high school of business management; and (2) the influence of school leadership, pedagogical and professional competences of teacher's on accounting teacher's performance at vocational high school of bussines management in klaten district. This research was ex-post facto quantitative approach. The population of this research simultaneously as sample was all of accounting teachers in Klaten District which involved 73 teachers and 15 schools. The data were collected by questionnaires. Analyzing data referred to descriptive analysis and multiple regression analysis. The results of this study are as follows. (1) There is no influence of Professional Competence on accounting teacher's performance at vocational high school of bussines management in Klaten district $(\mathrm{t}=0.643$, sig $=0.522)$. (2) There is an influence of
\end{abstract}


school leadership, pedagogical and professional competences on accounting teacher's performance at vocational high school of bussines management in Klaten district $(\mathrm{F}=$ 33.584$, sig $=0.000)$.

Keyword: Teacher,s perfomance, vocational high school

\section{A. Pendahuluan}

Pendidikan memegang peranan penting dalam upaya mewujudkan kualitas sumber daya manusia. Pada era globalisasi persaingan dalam segala bidang menjadi sangat ketat, hanya orang-orang yang mempunyai kemampuan dan kecakapan yang memenuhi kualifikasi yang akan tampil sebagai pemenang. Pendidikan kejuruan mempunyai peran strategis dalam upaya mengembangkan sumber daya manusia (SDM). Orientasi pendidikan kejuruan adalah menyiapkan peserta didiknya untuk memasuki dunia kerja. ${ }^{1}$ Undang-undang Republik Indonesia Nomor 20 Tahun 2003 tentang Sistem Pendidikan Nasional pasal 15 menjelaskan bahwa pendidikan kejuruan merupakan pendidikan menengah yang mempersiapkan peserta didik terutama untuk bekerja dalam bidang tertentu. Dalam pendidikan salah satu faktor yang berpengaruh dalam mencetak sumber daya manusia yang berkualitas adalah guru. Oleh karena itu seorang guru harus memiliki kinerja yang baik.

${ }^{2}$ Donni Juni Priansa (2014, p.269) menuliskan bahwa kinerja merupakan perwujudan dari kemampuan dalam bentuk karya nyata. Selain itu, kinerja merupakan hasil atau keluaran dari suatu proses, ${ }^{3}$ Nurlaila (2010, p.71). Jadi kinerja guru adalah kemampuan seorang guru untuk melakukan perbuatan sesuai dengan tujuan yang telah ditetapkan, yang mencakup aspek perencanaan program belajar mengajar, pelaksanaan proses belajar mengajar, penciptaan dan pemeliharaan kelas yang optimal, pengendalian kondisi belajar yang optimal, serta penilaian hasil belajar. Kinerja sangat penting dalam menentukan kualitas kerja seseorang, termasuk seorang guru.

Berdasarkan hasil pengamatan awal, kinerja guru Sekolah Menengah Kejuruan di Kabupaten Klaten, salah satunya dilihat dari hasil uji sertifikasi melalui portofolio. Data Dinas Pendidikan Kabupaten Klaten, guru SMK Bisnis Manajemen di Kabupaten Klaten yang sudah bersertifikasi sejumlah 552 orang dan yang belum bersertifikasi 1.457 orang. Berdasarkan data tersebut terlihat bahwa guru SMK di Kabupaten Klaten masih banyak yang belum bersertifikasi dan menunjukkan bahwa kinerja guru masih sangat rendah.

Pembelajaran di sekolah sangat penting diperhatikan dalam setiap aspeknya. Setiap pembelajaran mempunyai tujuan yang hendak dicapai. Dalam pencapaian tujuan pembelajaran perlu didukung kualitas pembelajaran yang baik. Salah satu komponen penting dalam proses pembelajaran adalah guru. Guru mempunyai peran besar dalam meningkatkan kualitas

1 Undang-undang Republik Indonesia Nomor 20 Tahun 2003. Sistem Pendidikan Nasional, Jakarta: CV. Eko Jaya, 2003)

2 Donni Juni Priansa. Perencanaan \& Pengembangan SDM (Bandung: Alfabeta, 2014). h.269.

3 Nurlaila. Manajemen Sumber Daya Manusia. (Ternate: Lepkhair, 2010). h.71. 
pembelajaran di kelas. Hal ini didukung hasil penelitian Murphy dalam E. Mulyasa (2008) mengemukakan bahwa "keberhasilan pembaharuan sekolah sangat ditentukan oleh gurunya, karena guru adalah pemimpin pembelajaran, fasilitator, dan sekaligus merupakan pusat inisiatif pembelajaran.

Guru sebagai pengajar berperan dalam merencanakan dan melaksanakan pembelajaran. Dalam melaksanakan pembelajaran diperlukan berbagai keterampilan. Keterampilan sangat diperlukan agar guru dapat bersikap profesional dalam mengelola kegiatan pembelajaran, sehingga dapat tercipta pembelajaran yang efektif dan efisien. Menurut ${ }^{5}$ Peraturan Pemerintah Republik Indonesia (PP RI) Pasal 28 No. 19 tahun 2005 tentang Standar Nasional Pendidikan, pendidik adalah agen pembelajaran yang harus memiliki empat jenis kompetensi, yakni kompetensi pedagogik, kepribadian, profesional, dan sosial. Dalam konteks tersebut, maka kompetensi guru dapat diartikan sebagai kebulatan pengetahuan, keterampilan dan sikap yang diwujudkan dalam bentuk perangkat tindakan cerdas dan penuh tanggung jawab yang dimiliki seseorang guru untuk memangku jabatan guru sebagai profesi.

Berdasarkan Peraturan Pemerintah di atas, dapat diketahui bahwa guru harus memiliki kompetensi yang menunjang dalam menciptakan pembelajaran yang berkualitas. Salah satunya adalah Kompetensi Pedagogik. Dalam Standar Nasional Pendidikan, penjelasan Pasal 28 ayat (3) butir a dikemukakan bahwa kompetensi pedagogik adalah kemampuan mengelola pembelajaran peserta didik yang meliputi pemahaman terhadap peserta didik, perancangan dan pelaksanaan pembelajaran, evaluasi hasil belajar, dan pengembangan peserta didik untuk mengaktualisasikan berbagai potensi yang dimilikinya. Kompetensi pedagogik bagi guru diperlukan agar guru dapat melaksanakan perannya dalam pengelolaan proses pembelajaran, sehingga pembelajaran dapat berjalan efektif dan efisien.

Masih rendahnya kinerja guru seperti guru mengajar secara monoton dan tanpa persiapan yang matang. Guru masih menggunakan persiapan mengajar dengan sangat sederhana, belum sepenuhnya menggunakan acuan kurikulum yang dipersyaratkan, dan tidak konsisten dalam implementasi skenario rencana pelaksanaan pembelajaran (RPP) yang telah dipersiapkan dan pada proses pembelajaran guru masih dominan menggunakan metode ceramah. Mengajar tidak sesuai dengan kompetensinya, struktur tugas yang tidak jelas, jadwal kerja yang tumpang tindih.

Kelemahan guru dalam hal ketrampilan dasar mengajar atau pada aspek kompetensi pedagogik antara lain: guru kurang bisa mengelola kelas dengan baik terbukti dengan banyaknya siswa yang berbicara sendiri dengan teman sebangku, guru belum menggunakan berbagai variasi media, siswa tidak aktif dalam pembelajaran, dan guru tidak mengondisikan peserta didik ketika akan memulai pembelajaran. Selain itu guru mengajar hanya berdasarkan pengalaman masa lalunya dari waktu kewaktu, sehingga merasa hafal diluar kepala dan tidak mau berubah terhadap hal-hal baru, termasuk metode pembelajaran, sistem penilaian yang kurang difahami, mengajar

4 Mulyasa, Menjadi Guru Profesional Menciptakan Pembelajaran Kreatif dan Menyenangkan (Bandung: Remaja Rosdakarya, 2008). H. 10.

5 Peraturan Pemerintah Republik Indonesia Nomor 19 Tahun 2005 tentang Standar Nasional Pendidikan 
secara hafalan/ tanpa persiapan mengajar. Hal ini sangat mempengaruhi kondisi pembelajaran di kelas. Kondisi pembelajaran yang baik akan berpengaruh terhadap daya serap siswa terhadap materi pelajaran. Kondisi pembelajaran yang menyenangkan akan membuat siswa bergairah untuk mengikuti pembelajaran. Jika sebaliknya, akan membuat siswa tidak berkonsentrasi terhadap materi yang diberikan.

\section{B. Kinerja Guru}

Donni Juni Priansa (2014, p.269) menuliskan bahwa ${ }^{6}$ kinerja merupakan perwujudan dari kemampuan dalam bentuk karya nyata. . Selain itu, kinerja merupakan hasil atau keluaran dari suatu proses, ${ }^{7}$ Nurlaila (2010, p.71). Maksud pernyataan tersebut seorang yang memiliki kemampuan yang memadai dan terampil dalam mengerjakan pekerjaan sehari-hari, maka ia akan lebih mudah mencapai kinerja yang diharapkan. Oleh karena itu, pegawai perlu ditempatkan pada pekerjaan yang sesuai dengan keahliannya.

Kinerja yang akan di bahas dalam penelitian ini yaitu kinerja guru. Kemampuan kerja guru di dalam melaksanakan tugasnya dalam mengajar serta kemampuannya untuk mencapai tujuan yang telah ditetapkan. Kinerja seorang guru mempunyai hubungan yang sangat erat dengan masalah produktivitas.

Tupele \& Ebi Enai (2014, p.141) menyatakan bahwa ${ }^{8 " G u r u ~ m e m i l i k i ~ t a n g g u n g ~ j a w a b ~}$ utama untuk mengajar siswa mereka tidak hanya pada kegiatan akademik tetapi juga pada kegiatan ekstrakurikuler dan tanggung jawab sosial”. Melihat pentingnya peran guru dalam meningkatkan produktifitas sekolah, oleh karena itu penilaian terhadap kinerja guru harus dilaksanakan untuk mengetahui seberapa besar kinerja seorang guru.

Gibson. Donni Juni Priansa, (2014, p.270) menyatakan bahwa "'faktor-faktor yang mempengaruhi kinerja pegawai adalah variabel individu, variabel psikologis, maupun variabel organisasi”. Berdasarkan uraian di atas yang dimaksud dengan kinerja guru dalam penelitian ini adalah kemampuan guru untuk melakukan suatu perbuatan sesuai dengan tujuan yang telah ditetapkan. Hal ini tercermin pada kemampuan guru sehubungan dengan tugasnya dalam proses belajar dengan indikator sebagai berikut: (1) kemampuan menyusun program pengajaran. (2) kemampuan menyajikan program pengajaran. (3) kemampuan menganalisis hasil belajar. (4) kemampuan menyusun program perbaikan dan pengayaan. (5) kemampuan menyusun program bimbingan.

Kepemimpinan Kepala Sekolah

Berkaitan dengan definisi kepemimpinan, Robbins \& Judge (2013, p.402) yang menuliskan bahwa ${ }^{10 " . . ., ~ l e a d e r s h i p ~ a s ~ t h e ~ a b i l i t y ~ t o ~ i n f l u e n c e ~ a ~ g r o u p ~ t o w a r d ~ t h e ~ a c h i e v e m e n t ~ o f ~ a ~ v i s i o n ~ o r ~}$

6 Donni Juni Priansa. Perencanaan \& pengembangan SDM. (Bandung: Alfabeta, 2014). H. 269.

7 Nurlaila. Manajemen Sumber Daya Manusia. (Ternate: Lepkhair, 2010).h. 71.

8 Tupele \& Ebi Enai, "Social capital and the teacher student relationship," Journal of education and practice No. 5, Vol. 11, 2014.

9 Donni Juni Priansa. Perencanaan \& Pengembangan SDM. (Bandung: Alfabeta, 2014).h.270.

10 Robbins \& Judge. Organizational behavior. ( New York: Pearson education limited, 2013).h.402. 
set of goals". Senada dengan hal tersebut, Zaib \& Harun (2014, p.132) menuliskan bahwa 11 "Leadership is described as the ability of an individual to influence, motivate and enable others to contribute toward the effectiveness in decision making process and setting the goal for the organization". Dengan demikian, kepemimpinan adalah pola menyeluruh dari tindakan seorang pemimpin, baik yang tampak maupun yang tidak tampak oleh bawahannya. Melalui kepemimpinan, seorang pemimpin (dalam hal ini adalah kepala sekolah) dapat mempengaruhi seluruh anggota atau komponen sistem sekolah sehingga melaksanakan tugas dan tanggung jawabnya menuju pencapaian visi sekolah.

Kompetensi Pedagogik Guru

Syaiful Sagala (2009, p.23) menyatakan bahwa ${ }^{12 " k o m p e t e n s i ~ m e r u p a k a n ~ p e l e b u r a n ~ d a r i ~}$ pengetahuan (daya pikir), sikap (daya kalbu), dan ketrampilan (daya pisik) yang diwujudkan dalam bentuk perbuatan'. Kompetensi (competency) didefinisikan dengan berbagai cara, namun pada dasarnya kompetensi merupakan kebulatan penguasan pengetahuan, keterampilan, dan sikap yang ditampilkan melalui unjuk kerja, yang diharapkan bisa dicapai seseorang setelah menyelesaikan suatu program pendidikan.

Jones, Voorhees, \& Paulson (2002, p.1) menyatakan bahwa, ${ }^{13}$ "a competency is a combination of skills, abilities, and knowledge needed to perform a specific task in a given context". Kompetensi merupakan kombinasi dari keterampilan, kemampuan atau kecapakan, dan pengetahuan yang diperlukan untuk melakukan tugas tertentu dalam konteks tertentu. Kompetensi merupakan suatu kemampuan spesisik yang memberikan ciri dan karakteristik tertentu yang membedakan manusia satu dengan manusia lainnya. E. Mulyasa (2011, p.79) mengatakan ${ }^{14}$ kompetensi pedagogik sangat penting karena menjadi penentu bagi keberhasilan proses belajar yang langsung menyentuh kemampuan pembelajaran meliputi: Pengelolaan peserta didik, perencanaan, perencangan pelaksanaan, evaluasi hasil belajar dan pengembangan peserta didik terhadap potensi yang dimilikinya (1) menguasai karakteristik peserta didik, (2) menguasai teori belajar, (3) mengembangkan kurikulum, (4) menyelenggarakan pembelajaran, (5) memanfaatkan teknologi informasi, (6) mengembangkan potensi peserta didik, (7) berkomunikasi secara efektif, (8) melaksanakan penilaian, (9) memanfaatkan hasil penilaian untuk kepentingan pembelajaran, (10) melakukan reflektif”.

Seorang guru bisa dikatakan profesional apabila guru tersebut bisa memahami aspek-

11 Zaib \& Harun, "Leadership in technical and vocational education," Journal of education and practice, No. 23, Vol, 132, 2014.

12 Syaiful Sagala, Kemampuan Profesional Guru dan Tenaga Kependidikan. (Bandung: Alfabeta, 2009).h.23.

13 Jones, Voorhees \& Paulson. Defining and assessing learning: exploring competency based initiatives. (Washington: National center for education statistics, 2002).h.1.

14 E.Mulyasa, Standar Kompetensi dan Sertifikasi Guru, (Bandung: Remaja Rosdakarya, 2011).h. 79. 
aspek kompetensi pedagogik dengan mengembangkan wawasan mendalam dalam penguasaan pengajaran peserta didik. Sebelum memulai pembelajaran guru menyiapkan perangkat pembelajaran dari mulai perancangan sampai dengan evaluasi. Kegiatan ini penting untuk mempermudah siswa memahami materi pelajaran dan untuk mengetahui seberapa jauh penguasaan materi oleh siswa. Kegiatan pengembangan peserta didik juga harus dikembangkan oleh guru karena untuk mengaktualisaskian berbagai potensi yang dimiliki oleh setiap peserta didik.

Kompetensi Profesional Guru

Moreno Rubio (2009, p.37) menyatakan bahwa ${ }^{15}$ guru yang efektif akan memperhatikan kompetensi profesional, dimana guru yang memiliki kompetensi profesional akan mendedikasikan diri mereka kepada siswa untuk mengajar dengan baik dan merasa bertanggung jawab atas prestasi dan keberhasilan siswa. Sanghi (2007, p.9) menyatakan bahwa, ${ }^{16 " C o m p e t e n c e s ~ r e f e r s ~ t o ~ t h e ~ r a n g e ~}$ of skills which are satisfactorily performed, while competencies refers to the behaviour adopted in competent performance". Kompetensi merupakan susunan atau kumpulan keterampilan yang ditunjukan secara profesional. Kompetensi mengacu pada perilaku dan kebiasaan yang dianut dibuktikan dengan unjuk kerja yang kompeten. Menurut Sanghi, definisi kompetensi berkaitan dengan knowledge yang dilatih dengan reading, skills dengan practising, dan competence dengan applying.

Guru yang bermutu mampu melaksanakan pendidikan, pengajaran dan pelatihan yang efektif dan efisien. Guru yang profesional diyakini mampu memotivasi peserta didik untuk mengoptimalkan potensinya dalam kerangka pencapaian standar pendidikan yang ditetapkan. Adapun indikator kompetensi profesional menurut Husaini Usman (2004) ${ }^{17}$ meliputi: (1) penguasaan terhadap landasan kependidikan, (2) menguasai bahan pengajaran, (3) kemampuan menyusun program pengajaran, (4) kemampuan menyusun perangkat penilaian hasil belajar dan proses pembelajaran.

\section{Metode Penelitian}

\section{Jenis Penelitian}

Jenis penelitian yang digunakan dalam penelitian ini adalah penelitian ex post facto. Penelitian ini mencari data empirik yang sistematik dan peneliti tidak dapat mengontrol langsung variabel bebas karena peristiwanya telah terjadi dan menurut sifatnya tidak dapat dimanipulasi.

15 Moreno Rubio, "Effective teacher: Proessional and personal skills,"Jurnal Elektronik Fakultas Pendidikan Universitas ENSAYOS No.24, 2009. h. 35-46

16 Sanghi. The handbook of competency mapping; Understanding, designing and implementing competency model in organizations (New Delhi: Sage Publications Inc, 2007).h. 9.

17 Husaini Usman. Manajemen: Teori, praktik dan riset pendidikan. (Jakarta: Bumi Aksara, 2014). h. 39 . 
Pendekatan yang digunakan dalam analisis data yaitu pendekatan kauntitatif. Dengan demikian pengaruh variabel bebas terhadap variabel terikat yang diteliti lebih bersifat pengaruh sebab akibat.

\section{Tempat dan Waktu Penelitian}

Penelitian ini dilaksanakan di SMK Kabupaten Klaten, khususnya SMK bidang keahlian Bisnis Manajemen, dengan Program Keahlian Akuntansi. Adapun pelaksanaannya yaitu bulan November 2015 - Agustus 2016.

\section{Populasi dan Sampel}

Populasi dalam penelitian ini sekaligus sebagai sampel, karena sampel yang digunakan kurang dari 100. Jumlah seluruh guru yang mengajar produktif kompetensi keahlian Akuntansi SMK Bisnis Manajemen di Kabupaten Klaten sejumlah 73 guru dari 15 sekolah. Sehingga total keseluruhan guru akuntansi di SMK Bisnis Manajemen Kabupaten Klaten sebanyak 73 guru digunakan sebagai subjek penelitian.

\section{Teknik Pengumpulan Data}

Teknik pengumpulan data yang digunakan dalam penelitian ini yaitu kuesioner (angket). Teknik kuesioner digunakan untuk mendapatkan data tentang kinerja guru, kepemimpinan kepala sekolah, kompetensi pedagogik, dan kompetensi profesional dengan guru yang menjadi responden.

\section{Instrumen Pengumpulan Data}

Penyusunan instrumen dalam penelitian ini dilakukan dengan beberapa tahap, yaitu: a) tahap penentuan indikator dari empat variabel penelitian, b) penyusunan kisi-kisi instrumen, c) pembuatan butir-butir pernyataan, dan d) melakukan uji coba instrumen. Kisi-kisi instrumen meliputi instrumen kinerja guru, kepemimpinan kepala sekolah, kompetensi pedagogik, dan kompetensi profesional.

Instrumen penelitian yang berupa angket disusun dan dikembangkan peneliti berdasarkan kajian teori yang dilakukan. Jawaban untuk angket dari pernyataan positif, yaitu jawaban mendukung gagasan kriteria penskorannya yaitu "selalu" skor 4, "sering" skor 3, "kadangkadang" skor 2, "tidak pernah" skor 1 .

\section{Validitas dan Reliabilitas Instrumen}

a. Uji Validitas

Uji validitas bertujuan untuk mengetahui sejauh mana instrumen pengukur mampu mengukur apa yang ingin diukur. Suatu kuesioner dikatakan valid jika pertanyaan pada kuesioner mampu untuk mengungkapkan sesuatu yang akan diukur oleh kuesioner tersebut. Uji validitas dalam penelitian ini menggunakan expert judgement dan uji empirik dengan ujicoba pada 
responden. Uji validitas dengan expert judgement dilakukan oleh ahli dalam bidang penilaian kinerja guru dan bisnis manajemen yaitu Prof. Dr. Husaini Usman, M.Pd., M.T dan Prof. Dr. Sukidjo, M.Pd

b. Reliabilitas Instrumen

Uji Reliabilitas dimaksudkan untuk mengetahui konsistensi instrumen atau angket sebagai alat ukur untuk pengambilan data penelitian. Reliabilitas menunjukkan tingkat kepercayaan dari suatu indikator yang digunakan dalam penelitian. Pengujian reliabilitas dilakukan dengan bantuan program spss for windows release 16.00. Teknik yang digunakan yaitu dengan menggunakan uji statistik Cronbach Alpha $(\alpha)$. Suatu variabel dikatakan reliabel jika memberikan nilai Cronbach Alpha> 0,60.

\section{Teknis Analisis Data}

a. Analisis Deskriptif Variabel Penelitian

Analisis deskriptif digunakan untuk mendeskripsikan masing-masing variabel penelitian yaitu kinerja guru, kepemimpinan kepala sekolah, kompetensi pedagogik, dan kompetensi profesional meliputi penyajian data nilai rata-rata (mean), nilai data tertinggi (maximum), nilai data terendah (minimum), dan standar deviasi (standard deviation). Pengukuran pada variabel yang dilakukan dengan memberikan skor dari jawaban angket yang diisi oleh responden. Deskripsi variabel penelitian ini dianalisis dengan menggunakan bantuan program SPSS for windows release 16.00 .

b. Uji Prasyarat Analisis

1) Uji Normalitas

Pada penelitian ini uji normalitas diuji dengan analisis Kolmogorov Smirnov dengan bantuan SPSS for windows release 16,0. Untuk menguji normalitas maka distribusi populasi diajukan hipotesis yaitu: Ho: databerasal dari populasi yang berdistribusi normal, dan Ha: databerasal dari populasi yang tidak berdistribusi normal. Jika didapatkan hasil nilai signifikansinya $>0,05$ maka data tersebut berdistribusi normal.

2) Uji Linieritas

Uji linieritas dalam penelitian ini menggunakan persamaan garis regresi/ regresi ganda dengan bantuan program SPSS for windows release 16,0. Pengujian linieritas garis regresi dalam penelitian ini menggunakan pendekatan analisis tabel Anova. Dasar pengambilan keputusan dari uji ini yaitu jika nilai koefisien $\mathrm{F}$ hitung lebih besar lebih besar $\mathrm{F}$ tabel dan nilai signifikansi $<(\alpha)=0,05$, maka dapat dikatakan linier.

3) Uji Multikolinieritas

Ada tidaknya korelasi antarvariabel independen dapat diketahui dengan memanfaatkan statistik korelasi product moment dari Pearson. Adapun hipotesis yang akan diuji untuk membuktikan ada tidaknya multikolinieritas antarvariabel bebas yaitu: Ho: tidak terdapat hubungan antarvariabel independen, Ha: terdapat hubungan antarvariabel independen. 
Untuk uji multikolinearitas dalam penelitian ini peneliti menggunakan bantuan program SPSS for windows release 16.00 .

4) Uji Heteroskedastisitas

Dalam penelitian ini uji heterokesdasitas dilakukan dengan uji Glejser. Uji Glejser ini yaitu dengan meregres nilai absolute residual terhadap variabel independen dengan persamaan regresi $|\mathrm{Ut}|=\mathrm{a}+\mathrm{BX} \mathrm{t}+\mathrm{vt}$. Dasar pengambilan keputusan pada uji heteroskedastisitas yaitu: (1) jika nilai signifikansi lebih besar dari 0,05, kesimpulannya adalah tidak terjadi heteroskedastisitas, dan (2) jika nilai signifikansi lebih kecil dari 0,05, kesimpulannya adalah terjadi heteroskedastisitas. Uji Heteroskedastisitas pada penelitian ini dengan bantuan program SPSS for windows release 16.00.

c. Analisis Regresi Linier Berganda

Model regresi linier berganda diperoleh dari hasil analisis regresi ganda. Analisis regresi ganda digunakan untuk meramalkan bagaimana keadaan (naik turunnya) variabel dependen (kriterium), apabila dua atau lebih variabel independen sebagai faktor prediktor dimanipulasi (dinaikkan atau diturunkan) nilaianya (Sugiyono, 2005: 250). Persamaan regresi untuk n prediktor adalah:

$$
\widehat{Y}=a+b_{1} X_{1}+b_{2} X_{2}+\cdots+b_{n} X_{n}
$$

\section{Uji Hipotesis}

1. Terdapat Pengaruh Kompetensi Profesional Guru Terhadap Kinerja Guru SMK Bisnis Manajemen di Kabupaten Klaten (H3)

Adapun untuk membuktikan kebenaran hipotesis 3 (H3) digunakan analisis koefisien t dari hasil perhitungan regresi linier berganda. Analisis koefisien tbertujuan untuk mengetahui ada tidaknya pengaruh antara variabel independen dan dependen, di mana salah satu atau lebih variabel independen lainnya dalam keadaan tetap atau dikontrol.

Keofisien tuntuk hipotesis 1 dinyatakan sebagai koefisien regresi Y dan X3, dengan mengontrol X1 dan X2.Oleh karena itu, hipotesis yang dikemukakan untuk menguji pengaruh $\mathrm{X} 3$ terhadap variabel $\mathrm{Y}$ yaitu sebagai berikut:

Ho : Tidak terdapat pengaruh X3 terhadap variabel Y secara signifikansi dan positif apabila variabel X1 dan X2tetap atau dikendalikan.

Ha: Terdapat pengaruh X3 terhadap variabel $\mathrm{Y}$ secara signifikansi dan positif apabila variabel X1 dan X2 tetap atau dikendalikan.

2. Terdapat Pengaruh Kepemimpinan Kepala Sekolah, Kompetensi Pedagogik, dan Kompetensi Profesional Guru Secara Bersama-Sama Terhadap Kinerja Guru SMK Bisnis Manajemen di Kabupaten Klaten (H4)

Adapun untuk membuktikan kebenaran hipotesis 4 (H4) digunakan analisis koefisien F dari hasil perhitungan regresi linier berganda. Koefisien $F$ merupakan angka yang menunjukkan pengaruh antara dua variabel atau lebih secara bersama-sama dengan variabel 
lain. Korelasi ini digunakan untuk menguji hipotesis 4 yaitu:

Ho: Tidak ada pengaruh antara kepemimpinan kepala sekolah, kompetensi pedagogik, dan kompetensi profesional guru secara bersama-sama terhadap kinerja guru SMK Bisnis Manajemen di Kabupaten Klaten.

Ha: Ada pengaruh antara kepemimpinan kepala sekolah, kompetensi pedagogik, dan kompetensi profesional gurusecara bersama-sama terhadap kinerja guru SMK Bisnis Manajemen di Kabupaten Klaten.

\section{Hasil Penelitian dan Pembahasan}

Hasil analisis deskriptif varabel kinerja guru (Y), kepemimpinan kepala sekolah (X1), kompetensi pedagogik (X2), dan kompetensi porfesional (X3) dapat dilihat pada Tabel 4 berikut:

Tabel 4. Hasil Analisis Deskriptif Variabel Penelitian

\begin{tabular}{|l|c|c|c|c|c|c|}
\hline \multicolumn{1}{|c|}{ Variabel } & $\mathrm{N}$ & Minimum & Maximum & Sum & Mean & Std. Deviation \\
\hline Kinerja_Guru & 73 & 64 & 96 & 5993 & 82.10 & 7.294 \\
Kepemimpinan_Kepala__ & 73 & 123 & 196 & 12321 & 168.78 & 17.812 \\
Sekolah_ & 73 & 51 & 76 & 4663 & 63.88 & 6.589 \\
Kompetensi_Pedagogik & 73 & 17 & 36 & 2009 & 27.52 & 4.253 \\
Kompetensi_Profesional & 73 & & & & & \\
Valid N(listwise) & 73 & \\
\hline
\end{tabular}

Data variabel kinerja guru diperoleh dari angket atau kuesioner dengan jumlah pernyataan sebanyak 28 butir dengan indikator: (1) dorongan pribadi, (2) dampak terhadap hasil, (3) kekuatan analisis, (4) berfikir strategis, (5) berfikir kreatif, (6) ketegasan, (7) manajemen tim dan kepemimpinan, (8) hubungan interpersonal, (9) kemampuan berkomunikasi, (10) kemampuan beradaptasi, dan (11) kemampuan merencanakan.

Hasil analisis deskriptif pada Tabel 4 dapat diketahui bahwa jumlah responden yang variabel kinerja guru yaitu sebanyak 73 guru dengan total skor 5993. Dari hasil perhitungan tersebut tampak pula nilai data terkecil (minimum) yaitu 64 dan nilai data terbesar (maximum) yaitu 96 dan, serta nilai rata-rata (mean) yaitu 82,10 dengan standar deviasi (standard deviation) 7,29. Hal tersebut menunjukkan bahwa data yang digunakan dalam variabel kinerja guru mempunyai sebaran kecil karena nilai standar deviasi lebih kecil dari nilai rata-ratanya (mean), sehingga simpangan data pada variabel kinerja guru ini dapat dikatakan baik.

\section{Deskripsi Variabel Kinerja Guru}

Variabel kinerja guru butir instrumen sebanyak 28 butir pertanyaan dengan 4 pilihan, adapun secara rinci deskripsi kinerja guru SMK Bisnis Manajemen di Kabupaten Klaten berdasarkan kriteria mutlak yang telah ditetapkan dapat dilihat pada tabel 5 sebagai berikut. 
Tabel 5. Kategori Kecenderungan Variabel Kinerja Guru

\begin{tabular}{|r|r|c|c|l|}
\hline No. & Interval & F & Persentase & \multicolumn{1}{|c|}{ Kategori } \\
\hline 1. & $\geq 92$ & 7 & 10 & Sangat Tinggi \\
\hline 2. & $78-91$ & 46 & 63 & Tinggi \\
\hline 3. & $64-77$ & 20 & 27 & Cukup Tinggi \\
\hline 4. & $50-63$ & 0 & 0 & Rendah \\
\hline 5. & $\leq 49$ & 0 & 0 & Sangat Rendah \\
\hline \multicolumn{2}{|c|}{ Jumlah } & 73 & 100 & \\
\hline
\end{tabular}

Hasil perhitungan total skor yang diperoleh dari hasil pengisian angket oleh 73 responden yaitu sejumlah 5993. Selanjutnya, Tabel 5 kecenderungan kategorisasi variabel kinerja guru yaitu pada interval 78 - 91 sebanyak 46 guru (63\%) dengan kategori tinggi. Berdasarkan data tersebut dapat diambil kesimpulan bahwa kinerja guru SMK Bisnis Manajemen di Kabupaten Klaten dalam kategori tinggi.

\section{Deskripsi Variabel Kompetensi Profesional}

Variabel kompetensi profesional butir instrumen sebanyak 9 butir pertanyaan dengan 4 pilihan, adapun secara rinci deskripsi kompetensi profesional guru SMK Bisnis Manajemen di Kabupaten Klaten berdasarkan kriteria mutlak yang telah ditetapkan dapat dilihat pada tabel 8 sebagai berikut.

Tabel 8. Kategori Kecenderungan Variabel kompetensi profesional

\begin{tabular}{|c|c|c|c|c|}
\hline No. & Interval & F & Persentase & Kategori \\
\hline 1. & $\geq 30$ & 26 & 36 & Sangat Tinggi \\
\hline 2. & $26-29$ & 25 & 34 & Tinggi \\
\hline 3. & $21-25$ & 19 & 26 & Cukup Tinggi \\
\hline 4. & $17-20$ & 3 & 4 & Rendah \\
\hline 5. & $\leq 160$ & 0 & 0 & Sangat Rendah \\
\hline & Jumlah & 73 & 100 & \\
\hline
\end{tabular}

Hasil perhitungan total skor yang diperoleh dari hasil pengisian angket oleh 73 responden yaitu sejumlah 2009. Selanjutnya, Tabel 8 kecenderungan kategorisasi variabel kompetensi profesional yaitu pada interval $\geq 30$ sebanyak 26 guru (36\%) dengan kategori sangat tinggi. Berdasarkan data tersebut dapat diambil kesimpulan bahwa kompetensi profesional guru SMK Bisnis Manajemen di Kabupaten Klaten dalam kategori sangat tinggi.

\section{E. Hasil Analisis Data}

\section{Uji Prasyarat Analisis Regresi}

a. Uji Normalitas 
Berdasarkan hasil perhitungan normalitas data diketahui bahwa nilai Asymp. Sig. (2-tailed) pada residual sebesar 0,865 lebih besar dari 0,05. Oleh karena itu dapat disimpulkan bahwa data berdistribusi normal.

b. Uji Linearitas

Tabel 9. Ringkasan Hasil Analisis Linieritas Garis Regresi dan Simpulannya berdasarkan Koefisien F

\begin{tabular}{|l|l|l|c|c|c|}
\hline $\mathrm{N}_{0}$ & \multicolumn{1}{|c|}{ Variabel } & F hitung & $\mathrm{F}$ tabel & Kondisi & Simpulan \\
\hline 1 & Kinerja*Kepemimpinan & 2,270 & 2,74 & $\mathrm{~F}_{\mathrm{h}}<\mathrm{F}_{\mathrm{t}}$ & Linear \\
\hline 2 & Kinerja*Pedagogik & 0,776 & 2,74 & $\mathrm{~F}_{\mathrm{h}}<\mathrm{F}_{\mathrm{t}}$ & Linear \\
\hline 3 & Kinerja*Profesional & 1,354 & 2,74 & $\mathrm{~F}_{\mathrm{h}}<\mathrm{F}_{\mathrm{t}}$ & Linear \\
\hline
\end{tabular}

Berdasarkan Tabel 9, diketahui bahwa koefisien F Deviation from Linierity (DFL) lebih kecil dari koefisien $\mathrm{F}$ Tabel maka dapat disimpulkan bahwa data perolehan linear. Artinya bahwa garis regresi tersebut berbentuk linear sehingga dapat digunakan untuk memprediksikan besarnya variabel dependen.

c. Uji Multikolinieritas

Tabel 10. Ringkasan Hasil Analisis Multikolinieritas

\begin{tabular}{|l|c|c|}
\hline \multicolumn{1}{|c|}{ Variabel } & Tolerance & VIF \\
\hline Kepemimpinan Kepala Sekolah & 0,637 & 1,570 \\
\hline Kompetensi Pedagogik & 0,463 & 2,159 \\
\hline Kompetensi Profesional & 0,511 & 1,956 \\
\hline
\end{tabular}

Berdasarkan Tabel 10 diketahui bahwa besarnya tolerance untuk masing-masing variabel kurang dari 1 dan besarnya nilai VIF masing-masing variabel kurang dari 10, sehingga dapat disimpulkan bahwa tidak terjadi multikolinieritas pada model regresi yang dipakai.

d. Uji Heteroskedastisitas

Tabel 11. Ringkasan Hasil Analisis Heteroskedastisitas

\begin{tabular}{|l|c|c|}
\hline \multicolumn{1}{|c|}{ Variabel } & sig & Alpha \\
\hline Kepemimpinan Kepala Sekolah & 0,151 & 0,05 \\
\hline Kompetensi Pedagogik & 0,008 & 0,05 \\
\hline Kompetensi Profesional & 0,914 & 0,05 \\
\hline
\end{tabular}

Dari Tabel 11 diketahui bahwa dari ketiga variabel independen yang digunakan nilai sig nya lebih besar dari 0,05 atau tidak terjadi heteroskedastisitas. Oleh karena itu, dapat disimpulkan bahwa tidak terjadi heteroskedastisitas pada model regresi. 


\section{Analisis Regresi Linear Berganda}

Analisis koefisien $\mathrm{t}$ digunakan untuk mengetahui ada tidaknya pengaruh atau mengetahui hubungan antara variabel independen dan dependen, di mana salah satu atau lebih variabel independen lainnya dalam keadaan tetap atau dikontrol. Hasil analisis yang dilakukan, menghasilkan $t_{\text {hitung }}$ sebagai berikut:

a. Kepemimpinan kepala sekolah $\mathrm{t}_{\text {hitung }}=0,843$ dengan nilai signifikansi 0,402 untuk koefisien korelasi Y dan X1, dengan mengontrol X2 dan X3.

b. Kompetensi pedagogik guru $t_{\text {hitung }}=5,595$ dengan nilai signifikansi 0,000 untuk koefisien korelasi Y dan X2, dengan mengontrol X1 dan X3.

c. Kompetensi profesional guru $\mathrm{t}_{\text {hitung }}=0,643$ dengan nilai signifikansi 0,522 untuk koefisien korelasi Y dan X3, dengan mengontrol X1 dan X2.

d. Nilai t tabel dengan df 69 dan taraf signifikansi 0,05 adalah 1,667. Oleh karena itu pengambilan keputusan untuk menerima atau menolak hipotesis adalah sebagai berikut.

e. Hipotesis 1: $\mathrm{t}_{\text {hitung }}=0,843<\mathrm{t}_{\text {tabel }}=1,667$ dan nilai signifikansi $0,402>$ alpha 0,05 maka Ho diterima, sehingga dapat disimpulkan bahwa tidak terdapat pengaruh X1 terhadap variabel Y secara signifikans apabila variabel X2 dan X3 dikendalikan.

f. Hipotesis 2: $\mathrm{t}_{\text {hitung }}=5,595>\mathrm{t}_{\text {tabel }}=1,667$ dan nilai signifikansi $0,000<$ alpha 0,05 maka Ho ditolak dan Ha diterima, sehingga dapat disimpulkan terdapat pengaruh X2 terhadap variabel Y secara signifikansi dan positif apabila variabel X1 dan X3 dikendalikan.

g. Hipotesis 3: $\mathrm{t}_{\text {hitung }}=0,643<\mathrm{t}$ tabel $=1,667$ dan nilai signifikansi $0,522>$ alpha 0,05 maka Ho ditolak, sehingga dapat disimpulkan tidak terdapat pengaruh $\mathrm{X} 3$ terhadap variabel $\mathrm{Y}$ secara signifikans apabila variabel X1 dan X2 dikendalikan.

Berdasarkan hasil analisis koefisien regresi diketahui bahwa nilai konstanta yaitu 25,703, nilai koefisien regresi X1 sebesar 0.034, nilai koefisien regresi X2 sebesar 0,743, dan nilai koefisien regresi $\mathrm{X} 3$ sebesar 0,118 . Maka persamaan regresi ganda pada penelitian ini adalah:

$$
Y=25,703+0.034 X 1+0,743 \times 2+0,118 \times 3
$$

\section{Uji Hipotesis}

1. Terdapat Pengaruh Kompetensi Profesional Guru terhadap Kinerja Guru SMK Bisnis Manajemen di Kabupaten Klaten (H3)

Adapun untuk membuktikan kebenaran hipotesis $3(\mathrm{H} 3)$ digunakan analisis koefisien t. Hasil uji hipotesis 1 yang dilakukan diperoleh nilai $t_{\text {hitung }}$ variabel kompetensi profesional sebesar 0,643 dengan probabilitas 0,522. Nilai t tabel dengan df 69 dan taraf signifikansi 0,05 adalah 1,667. Oleh karena itu pengambilan keputusan untuk menerima atau menolak hipotesis 1 adalah $t_{\text {hitung }}=0,643<t_{\text {tabel }}=1,667$ dan nilai signifikansi $0,522>$ alpha 0,05 maka Ho diterima, sehingga dapat disimpulkan bahwa tidak terdapat pengaruh kompetensi profesional terhadap kinerja guru SMK Bisnis Manajemen di Kabupaten Klaten secara signifikan. 
82 Ita Nurmalasari

2. Terdapat Pengaruh Kepemimpinan Kepala Sekolah, Kompetensi Pedagogik, dan Kompetensi Profesional Guru Secara Bersama-Sama terhadap Kinerja Guru SMK Bisnis Manajemen di Kabupaten Klaten (H4)

Adapun untuk membuktikan kebenaran hipotesis 4 (H4) digunakan analisis koefisien F. Koefisien F merupakan angka yang menunjukkan pengaruh antara dua variabel atau lebih secara bersama-sama dengan variabel lain.Berdasarkan hasil analisis yang dilakukan diperoleh nilai $\mathrm{F}$ hitung $=33,584$ dengan signifikansi $=0,000$. Nilai $\mathrm{F}$ tabel dengan df1 $=$ 3 , df2 = 70 dan tingkat signifikansi 0,05 adalah 2,74. Oleh karena nilai $F$ hitung $=33,584$ $>$ dari $\mathrm{F}$ tabel dan nilai sig $=0,000<$ taraf signifikansi 0,05 maka Ho yang menyatakan tidak ada pengaruh ditolak. Sebagai konsekuensinya harus menerima Ha yang menyatakan ada pengaruh. Berdasarkan analisis di atas dapat disimpulkan ada pengaruh yang signifikan kepemimpinan kepala sekolah, kompetensi pedagogik dan kompetensi profesional secara bersama-sama terhadap kinerjaguru SMK Bisnis Manajemen di Kabupaten Klaten.

\section{F. Pembahasan}

\section{Pengaruh Kompetensi Profesional terhadap Kinerja Guru SMK Bisnis Manajemen di Ka- bupaten Klaten}

Hasil analisis deskriptif variabel kompetensi professional guru diketahui bahwa kecenderungan kategorisasi variabel kompetensi professional guru yaitu dalam kategori sangat tinggi. Ada dua indikator yang digunakan untuk mengukur varaibel kepemimpinan kepala sekolah ini, yaitu 1) penguasaan materi pembelajaran; dan 2) pengembangan profesi. Oleh karena itu, berdasarkan hasil penilaian guru akutansi dapat disimpulkan kepemimpinan kepala sekolah SMK Bisnis Manajemen di Kabupaten Klaten dalam kategori sangat tinggi.

Hasil uji hipotesis pertama dalam penelitian menyatakan bahwa terdapat pengaruh yang positif namun tidak signifikan kompetensi professional guru terhadap kinerja guru SMK Bisnis Manajemen di Kabupaten Klaten. Hal tersebut dibuktikan dengan nilai t hitung sebesar 0,643 lebih kecil dari t tabel sebesar 1,667 dan nilai signifikasi sebesar 0,522 yang lebih besar dari 0,05. Nilai koefisien regresi variabel kepemimpinan kepala sekolah memiliki arah positif berarti kompetensi professional guru memberikan pengaruh yang positif, namun pengaruh tersebut tidak signifikan terhadap kinerja guru apabila variabel kompetensi kepemimpinan kepala sekolah dan kompetensi pedagogik dalam keadaan tetap atau dikendalikan. Nilai koefisien regresi variabel kompetensi profesional sebesar 0,118 berarti harga koefisien tersebut tidak memberikan pengaruh yang signifikan terhadap kinerja guru.

Hasil temuan dalam penelitian ini bahwa secara teoritis kompetensi professional guru berpengaruh terhadap kinerja guru tidak terbukti. Berdasarkan hasil temuan tersebut maka dilakukan analisis lebih mendalam terkait kondisi dilapangan selama penelitian. Berdasarkan pengamatan peneliti selama pengambilan data ditemukan bahwa beberapa responden dalam pengisian angket untuk angket kompetensi profesional guru cenderung menilai dengan skor tinggi karena merasa bahwa dengan demikian dapat meningkatkan citra guru SMK di Kabupen 
Klaten mengingat hasil UKG yang rendah. Kusnandar (2013: 131) memberikan penjelasan bahwa ${ }^{18}$ kelemahan dari penilaian diri yaitu: 1) cenderung subjektif; 2) data mungkin ada yang pengisiannya tidak jujur; 3) dapat terjadi kemungkinan subjek yang dinilai menilai dengan skor tinggi; 4) hasil kurang akurat; dan 5) mungkin objek yang dinilai tidak memahami adanya kemampuan yang dimiliki.

2. Pengaruh Kepemimpinan Kepala Sekolah, Kompetensi Pedagogik, dan Kompetensi Profesional Guru Secara Bersama-Sama terhadap Kinerja Guru SMK Bisnis Manajemen di Kabupaten Klaten

Guru adalah tenaga pendidik yang berperan sebagai ujung tombak transformasi pengetahuan dan nilai sikap, pembentuk kepribadian peserta didik serta ikut bertanggung jawab tercapainya tujuan pendidikan. Oleh sebab itu guru terlibat langsung dalam proses pembelajaran di dalam kelas, maka guru dapat dikatakan sebagai komponen utama dalam proses pendidikan. Karena kedudukannya itulah, maka guru menempati posisi yang sangat penting dalam meningkatkan kualitas proses pembelajaran maupun hasilnya. Pada konteks ini, kualitas pendidikan sangat ditentukan oleh kualitas kinerja guru, yang konsekuensinya guru dituntut untuk berperan aktif dalam memposisikan diri sebagai tenaga profesional sesuai dengan tuntutan masyarakat yang semakin berkembang. Imam Wahyudi (2012) yang menyatakan ${ }^{19}$ kinerja guru adalah hasil kerja secara kualitas dan kuantitas yang dicapai oleh seorang guru dalam melaksanakan tugasnya sesuai dengan tanggung jawab yang dibebankan kepadanya yang meliputi menyusun program pembelajaran, pelaksanaan pembelajaran, pelaksanaan evaluasi, dan analisis evaluasi.

Berdasarkan uraian di atas dapat disimpulkan bahwa faktor yang mempengaruhi kinerja guru berasal dari internal dan eksternal guru. Setelah melakukan kajian yang mendalam, dalam penelitian ini faktor internal yang di duga kuat mempengarui kinerja guru yaitu kompetensi pedagogik dan kompetensi profesional guru, sedangkan faktor eksternal yang diduga sangat berpengaruh terhadap kinerja guru yaitu kepemimpinan kepala sekolah.

Hasil analisis deskriptif dalam penelitian ini ditemukan bahwakinerja guru SMK Bisnis Manajemen di Kabupaten Klaten dalam kategori tinggi. Hal ini dapat diketahui dari 73 orang guru sebagai responden, 46 guru (63\%) dalam kategori sangat tinggi. Temuan ini menggambarkan profesionalisme guru dari dilihat dari 3 indikator penilaian kinerja guru, yaitu 1) kemampuan merencanakan program pengajaran; 2) kemampuan melaksanakan kegiatan pembelajaran; dan 3) kemampuan melaksanakan penilaian dan evaluasi.

Hasil analisis regresi berganda menunjukkan bahwa kinerja guru dipengaruhi oleh kepemimpinan kepala sekolah, kompetensi pedagogik, dan kompetensi professional guru. Besarnya kemampuan variasi variabel kepemimpinan kepala sekolah, kompetensi pedagogik, dan kompetensi professional guru dalam menjelaskan variabel kinerja guru yaitu 59,4\%, sementara $41,6 \%$ variabel kinerja guru dijelaskan oleh variabel lain diluar model penelitian. Berdasarkan temuan tersebut maka variabel kepemimpinan kepala sekolah, kompetensi pedagogik, dan

18 Kusnandar. Guru profesional implementasi KTSP. (Jakarta: Grafindo persada, 2007). h. 131.

19 Imam Wahyudi. Pengembangan Pendidikan. (Jakarta: Prestasi Pustakarya, 2012). h. 86. 
kompetensi professional guru harus lebih diperhatikan, karena ketiga variabel tersebut memiliki kontribusi yang cukup tinggi terhadap peningkatan kinerja guru.

\section{G. Keterbatasan Penelitian}

1. Tidak semua angket diberikan langsung oleh peneliti kepada responden, tetapi ada sebagian yang diserahkan kepada ketua juruan akuntansi di sekolah yang dijadikan tempat penelitian untuk diberikan kepada responden, sehingga tidak diketahui apakah semua responden yang mengisi angket benar-benar guru yang mengajar mata pelajaran produktif akuntasi.

2. Karena keterbatasan waktu dan tenaga peneliti tidak melakukan pendampingan kepada semua responden saat pengisian angket, sehingga adanya kemungkinan pernyataan yang kurang dipahami oleh responden serta kesungguhan responden dalam pengisian angket ada yang tidak diketahui.

3. Beberapa guru terlihat mengajak guru lain untuk memberikan nilai tinggi pada kepemimpinan kepala sekolah karena ada rasa tidak enak pada pimpinan.

\section{H. Simpulan}

Berdasarkan hasil penelitian dan pembahasan maka dapat diambil kesimpulan sebagai berikut:

1. Tidak ada pengaruh yang signifikan Kompetensi Profesional guru terhadap kinerja guru akuntansi SMK Bisnis Manajemen di Kabupaten Klaten.

2. Ada pengaruh yang signifikan kepemimpinan kepala sekolah, kompetensi pedagogik, dan kompetensi profesional guru secara bersama-sama terhadap kinerja guru akuntansi SMK Bisnis Manajemen di Kabupaten Klaten.

\section{Bibliografi}

Donni Juni Priansa. (2014). Perencanaan \& pengembangan SDM. Bandung: Alfabeta

Husaini Usman. (2014). Manajemen: teori, praktik, dan riset pendidikan. Jakarta: Bumi Aksara

Imam Wahyudi. (2012). Pengembangan Pendidikan. Jakarta: Prestasi Pustakarya

Jones, E.A., Voorhees, R. A., \& Paulson, K. (2002). Defining and assessing learning: exploring competency-based initiatives. Washington: National Center for Education Statistics (NCES). 
Kusnandar. (2007). Guru profesional implementasi KTSP. Jakarta: Grafindo Persada

E. Mulyasa. (2008). Menjadiguru profesionalmenciptakan pembelajaran kreatifdan menyenangkan. Bandung : Remaja Rosdakarya. . (2011). Standar kompetensi dan sertifikasi guru. Bandung: Remaja Rosdakarya.

Rubio, M.C. (2009). Effective teachers: professional and personal skills. Jurnal Elektronik Fakulatas Pendidikan Universitas ENSAYOS. No.24, pp.35-46. http://www.uclm.es/ ab/education/ensanyos

Nurlaila. (2010). Manajemen sumber daya manusia. Ternate: Lepkhair

Republik Indonesia. (2005). Peraturan peerintah Nomor 19, Tahun 2005, tentang Standar Nasional Pendidikan.

Robbins, S.P., \& Judge, T.A. (2013). Organizational behavior. New York: Pearson Education Limited

Sanghi, S. (2007). The handbook of competency mapping; understanding, designing and implementing competency models in organizations 2nd edition. New Delhi. Sage Publications Inc.

Sagala. S. (2009). Kemampuan profesional guru dan tenaga kependidikan. Bandung: Alfabeta

Tupele, O., \& Enai, E. (2014). Social capital and the teacher student relationship. Journal of Education and Practice, 5, 11

Zaib \& Harun. (2014). Leadership in technical and vocational education: towards excellence human capital. Journal of education and practice, 23, 132. 
